УДК 327.7+341.1:339.92(477)

DOI: https://doi.org/10.37320/2415-3583/12.28

Ільченко Т.В.

кандидат економічних наук, доцент, Дніпровський державний аграрно-економічний університет ORCID: https://orcid.org/0000-0003-1879-6310

\title{
ПОЛІТИКО-ЕКОНОМІЧНІ ЗАСОБИ ІНТЕГРАЦІЇ УКРАЇНИ У СВРОПЕЙСЬКУ СПІЛЬНОТУ
}

Досліджено історію партнерських взаємовідносин Украӥни та ЄС. Встановлено, щео одним з ключових напрямів економічної інтеграчії с співпрачя з міжнародними фінансовими організачіями, які фінансують програми у різних сферах економічної діяльності. Виконано статистичний аналіз показників зведеного зовнішньоторговельного балансу Украӥни з краӥнами СС. Наведено результати проведених соиіологічних опитувань з метою виявлення рівня підтримки громадянами вступу Украйни до Свропейського Союзу. Запропоновано матрицю SWOTаналізу інтеграції України у Європейську спільноту. Визначено політико-економічні засоби інтеграції Украӥни у Свропейську спільноту в умовах реалізаиії Угоди про асоціацію, які можуть використовувати органи влади при доопрацюванні нормативно-правових актів з регулювання євроінтеграчійного процесу.

Ключові слова: європейська інтеграчія, єдиний європейський простір, політико-економічні засоби, режим партнерства, SWOT-аналіз, пріоритетні напрями співпраџі.

Постановка проблеми. Стратегічною метою України визнано інтеграцію у Свропейську спільноту. Це $є$ найкращим засобом реалізації національних інтересів, побудови демократичної держави, зміцнення політикоекономічних позицій у єдиному європейському просторі.

Для України європейська інтеграція є ключовим напрямом модернізації й формування інноваційної моделі соціально-економічного розвитку, залучення інвестиційних ресурсів та інноваційних технологій, створення нових робочих місць, підвищення конку- рентоспроможності вітчизняного товаровиробника, розширення ринків збуту. Головна перевага вступу України до СС полягає у можливості виходу країни на якісно новий рівень розвитку і формування партнерських взаємовідносин з провідними країнами Свропи в економічному й політичному плані.

Аналіз останніх досліджень і публікацій. Європейський інтеграційний процес $є$ непростим питанням, яке набуло особливої актуальності й активно обговорюється в останні десятиріччя в науковому та підпри- 
ємницькому середовищі [1-13]. Рябінін С. [5] досліджує генезис поняття «інтеграція» і визначає специфічні риси політичної інтеграції, а саме: незалежність, взаємодію, узгодженість, єдність. Українські вчені-науковці Осадча Н. В. [6], Тодощук А. В., Батюк I. I., Шеремета А. I. [10], Степаненко Н. О., Степаненко В. О. [11], Кваша О. С., Синякова А. В. [12] приділяють значну увагу SWOTаналізу з метою виявлення переваг і недоліків співпраці СC та України. Разом з тим, багатогранність, багатоаспектність і дискусійність окремих проблем 3 обраної тематики обумовлюють необхідність подальших наукових досліджень. Вирішення цієї проблеми актуалізується у сучасних умовах трансформації політико-економічних процесів у контексті глобалізації та євроінтеграції. Невирішеним залишилося питання визначення політикоекономічних засобів інтеграції України в Свропейську спільноту на підставі проведеного SWOT-аналізу, що й обумовило вибір даної теми дослідження.

Мета статті полягає у виявленні переваг, недоліків, загроз, ризиків, можливостей і перспективних напрямів європейської інтеграції за допомогою SWOTаналізу і визначенні політико-економічних засобів іiі реалізації в умовах України.

Виклад основного матеріалу. Відносини між Україною та Свропейським Союзом розпочалися у грудні 1991 р., а режим партнерства й співпраці почав впроваджуватися з 1993 р. (таблиця 1).

Одним з ключових напрямів економічної інтеграції України та СС є співпраця з міжнародними фінансовими організаціями, які фінансують програми у різних сферах економічної діяльності (таблиця 2).
Розглянемо зведений зовнішньоекономічний баланс України з країнами СС (таблиця 3)

Аналіз статистичних даних за 2010-2018 pp. свідчить про зростання обсягів експортно-імпортних операцій у зведеному зовнішньоторговельному балансі України з країнами СС. Так, за даними Державної служби статистики України, загальний обсяг експорту збільшився на 44\%, а імпорту - на $20,7 \%$. Однак сальдо експортно-імпортних операцій має від'ємне значення, хоча співвідношення між імпортом і експортом щороку скорочується: якщо у 2010 р. воно становило 1,37 рази, то у 2018 р. 1,15 рази (таблиця 3).

Проаналізуємо зовнішню торгівлю України товарами з країнами СС (таблиця 4, 5).

За досліджуваний період обсяги експорту товарів зросли на 56,1\%, а імпорту - на 22,2\%. Співвідношення між імпортом і експортом у 2018 р. становило 1,15 рази (у 2010 р. - 1,47 рази)

Обсяги експорту послуг збільшилися в 2018 р. порівняно з 2010 р. на 27,4\%, а імпорту - на 11,8\%. Спостерігається тенденція позитивного сальдо експортноімпортних операцій. При цьому співвідношення між експортом та імпортом послуг щорічно зростатиме. Якщо в 2010 р. значення цього показника становило 1,04 раза, то в 2018 р. - 1,19 рази

Однак, як показує аналіз, загальні обсяги прямих інвестицій з країн СС в економіці України скоротилися за 2010-2019 pр. на 21,1\%. Це обумовлено зниженням обсягів прямих інвестицій з країн ЄС-15 - на 36,4\% і ЄC-27 - на 23,5\% (таблиця 6).

Таблиця 1 - Історія партнерських взаємовідносин України та СС

\begin{tabular}{|c|c|}
\hline Період & Зміст \\
\hline грудень 1991 р. & $\begin{array}{l}\text { Лист Міністра закордонних справ Нідерландів від імені Європейського Союзу, у якому офіційно } \\
\text { визнано незалежність України }\end{array}$ \\
\hline 2 липня 1993 р. & Постанова Верховної Ради України «Про основні напрями зовнішньої політики України» \\
\hline 11 червня 1998 р. & $\begin{array}{l}\text { Стратегія інтеграції України до СС, у якій визначено стратегічний курс України на європейську } \\
\text { інтеграцію }\end{array}$ \\
\hline 14 вересня 2000 p. & $\begin{array}{l}\text { Програма інтеграції України до ЄС, у якій було проголошено довготермінову стратегічну мету - } \\
\text { європейська інтеграція України }\end{array}$ \\
\hline 5 березня 2007 р. & Переговорний процес щодо укладення нової угоди між Україною та СС \\
\hline 9 вересня 2008 р. & $\begin{array}{l}\text { на Паризькому саміті між Україною та ЄС досягнуто політичну домовленість про укладення } \\
\text { майбутньої угоди в форматі Угоди про асоціацію, яка будуватиметься на принципах політичної } \\
\text { асоціації та економічної інтеграції }\end{array}$ \\
\hline $2009 \mathrm{p}$. & $\begin{array}{l}\text { Розроблено та схвалено Порядок денний асоціації, який замінив План дій Україна - ЄС і мав } \\
\text { за мету бути орієнтиром для проведення реформ в Україні у процесі підготовки імплементації } \\
\text { майбутньої Угоди про асоціацію }\end{array}$ \\
\hline 1 липня 2010 p. & $\begin{array}{l}\text { Закон України «Про засади внутрішньої і зовнішньої політики»-у с. } 11 \text { вказано, що однією } 3 \\
\text { основоположних засад зовнішньої політики України є забезпечення інтеграції України в } \\
\text { європейський політичний, економічний, правовий простір з метою набуття членства в ЄС }\end{array}$ \\
\hline 19 грудня 2011 р. & На 15-му Саміті Україна-СС завершено переговори по майбутній Угоді про асоціацію \\
\hline 30 березня 2012 p. & Текст майбутньої Угоди було парафовано главами переговірних команд України та ЄС \\
\hline 21 березня 2014 р. & Підписано політичну частину Угоди про асоціацію \\
\hline 27 червня 2014 р. & Підписано економічну частину Угоди про асоціацію \\
\hline 16 вересня 2014 р. & $\begin{array}{l}\text { Верховною Радою України та Європейським Парламентом синхронно ратифіковано Угоду } \\
\text { про асоціацію між Україною та ЄС }\end{array}$ \\
\hline 31 листопада 2014 р. & Здійснювалося тимчасове застосування Угоди про асоціацію між Україною та ЄС \\
\hline 1 вересня 2017 р. & $\begin{array}{l}\text { Угода про асоціацію між Україною та ЄС повністю набула чинності. Це міжнародно-правовий } \\
\text { документ, який на договірно-правовому рівні закріплює перехід відносин між Україною та ЄС від } \\
\text { партнерства та співробітництва до політичної асоціації та економічної інтеграції }\end{array}$ \\
\hline
\end{tabular}

Джерело: адаптовано й складено за даними: [4, с. 17-21]. 
Таблиця 2 - Фінансування програм у рамках співпраці України та ЄС

\begin{tabular}{|l|c|}
\hline \multicolumn{1}{|c|}{ Види програм } & Обсяги фінансування, млн євро \\
\hline $\begin{array}{l}\text { Гуманітарна допомога громадянам, переміщеним із тимчасово окупованих територій } \\
\text { України; відновлення інфраструктри Донбасу (3 липня 2014 р.) }\end{array}$ & 400,0 \\
\hline $\begin{array}{l}\text { Макрофінансова допомога (позики на тривалий термін і за низькою відсотковою } \\
\text { ставкою) (за 2014-2018 рр.) }\end{array}$ & 6820,0 \\
\hline Загальнонаціональна програма децентралізації (з 2014 р.) & 90,0 \\
\hline Антикорупційна програма (з 2014 р.) & 15,0 \\
\hline Програма розвитку приватного сектору (з 2014 р.) & 104,0 \\
\hline Програма реформування державного управління (у 2016 р.) & 23,0 \\
\hline $\begin{array}{l}\text { Програма «Місцевий розвиток, орієнтований на громаду» за рахунок фінансування з } \\
\text { фондів Свропейського інструменту сусідства (за 2014-2017 рр.) }\end{array}$ & 90,0 \\
\hline Програми реформ децентралізації та регіональної політики U-LЕАD (у 2016 р.) & 200,0 \\
\hline Кредитування малого й середнього бізнесу & 10,0 \\
\hline Програма відновлення України & 100,0 \\
\hline Розвиток громадянського суспільства & 850,0 \\
\hline $\begin{array}{l}\text { Удосконалення транспортної (дорожньої та залізничної) інфраструктури на заході } \\
\text { України }\end{array}$ \\
\hline $\begin{array}{l}\text { Модернізація залізничної інфраструктури України у рамках інвестиційного плану дій } \\
\text { для розвитку інфраструктури в країнах «Східного партнерства» (Свропейська комісія } \\
\text { спільно зі Світовим банком) }\end{array}$ \\
\hline
\end{tabular}

Джерело: узагальнено й складено за даними: [12, с. 115]

Таблиця 3 - Зведений зовнішньоекономічний баланс України 3 країнами СС

\begin{tabular}{|c|c|c|c|}
\hline Роки & $\begin{array}{c}\text { Загальні обсяги експорту, } \\
\text { млн дол. США }\end{array}$ & $\begin{array}{c}\text { Загальні обсяги імпорту, } \\
\text { млн дол. США }\end{array}$ & $\begin{array}{c}\text { Сальдо, } \\
\text { млн дол. США }\end{array}$ \\
\hline 2010 & 16039,5 & 22004,5 & $-5965,0$ \\
\hline 2011 & 21395,8 & 28642,4 & $-7246,6$ \\
\hline 2012 & 20688,1 & 29675,1 & $-8987,0$ \\
\hline 2013 & 20159,0 & 30969,6 & $-10810,6$ \\
\hline 2014 & 20383,0 & 24207,6 & $-3824,6$ \\
\hline 2015 & 15339,5 & 18075,9 & $-2736,4$ \\
\hline 2016 & 15827,5 & 19558,7 & $-3731,2$ \\
\hline 2017 & 20157,6 & 23330,2 & $-3172,6$ \\
\hline 2018 & 23100,1 & 26570,1 & $-3470,0$ \\
\hline
\end{tabular}

Джерело: складено й розраховано за даними: [14, с. 12-13; 15, с. 12-13; 16, с. 6-7].

Таблиця 4 - Зовнішня торгівля України товарами з країнами СС

\begin{tabular}{|c|c|c|c|}
\hline Роки & Обсяги експорту, млн дол. США & Обсяги імпорту, млн дол. США & Сальдо, млн дол. США \\
\hline 2010 & 12916,4 & 19004,2 & $-6087,8$ \\
\hline 2011 & 17862,9 & 25270,3 & $-7407,4$ \\
\hline 2012 & 16937,9 & 26033,9 & $-9096,0$ \\
\hline 2013 & 16573,5 & 26766,9 & $-10193,4$ \\
\hline 2014 & 17002,9 & 21069,1 & $-4066,2$ \\
\hline 2015 & 13015,2 & 15330,2 & $-2315,0$ \\
\hline 2016 & 13496,3 & 17140,8 & $-3644,5$ \\
\hline 2017 & 17533,4 & 20799,4 & $-3266,0$ \\
\hline 2018 & 20157,0 & 23216,5 & $-3059,5$ \\
\hline
\end{tabular}

Джерело: складено й розраховано за даними: [14, с. 12-13; 15, с. 12-13; 16, с. 6-7]

14-30 травня 2019 р. Центром стратегічного розвитку територій було проведено соціологічне дослідження, у якому взяли участь 2116 респондентів із 124 населених пунктів із різною кількістю населення. Статистична похибка становить $2,2 \%$. У ході дослідження встановлено, що 69\% опитаних виступають за підтримку вступу України до СС (у 2012 р. - 42\%); $13 \%$ - проти; $18 \%$ не можуть визначитися зі своєю позицією.
$63 \%$ респондентів довіряють СС як партнеру України; $21 \%$ - не довіряють; $16 \%$ не змогли визначитися. Від євроінтеграції українці насамперед очікують розширення простору власних можливостей, кращої освіти, працевлаштування й медицини. При цьому гарантії безпеки визнано одним з ключових напрямів, на які очікують від партнерства з ЄС. До внутрішніх перешкод інтеграції України до ЄС респонденти віднесли високий рівень корупції, проблеми на Донбасі, 
Таблиця 5 - Зовнішня торгівля України послугами з країнами СС

\begin{tabular}{|c|c|c|c|}
\hline Роки & $\begin{array}{c}\text { Обсяги експорту, } \\
\text { млн дол. США }\end{array}$ & $\begin{array}{c}\text { Обсяги імпорту, } \\
\text { млн дол. США }\end{array}$ & $\begin{array}{c}\text { Сальдо, } \\
\text { млн дол. США }\end{array}$ \\
\hline 2010 & 3123,1 & 3000,3 & 122,8 \\
\hline 2011 & 3532,9 & 3372,1 & 109,8 \\
\hline 2012 & 3750,2 & 3641,2 & $-16,3$ \\
\hline 2013 & 4195,7 & 4212,0 & 842,8 \\
\hline 2014 & 3991,6 & 3148,8 & 177,8 \\
\hline 2015 & 2927,9 & 2750,1 & 583,3 \\
\hline 2016 & 3004,9 & 2421,6 & 920,2 \\
\hline 2017 & 3452,7 & 2532,5 & 624,1 \\
\hline 2018 & 3979,9 & 3355,8 & \\
\hline
\end{tabular}

Джерело: складено й розраховано за даними: [14, c. 12-13; 15, c. 12-13; 16, с. 6-7]

Таблиця 6 - Динаміка прямих інвестицій з країн СС в економіці України

\begin{tabular}{|c|c|c|c|}
\hline \multirow{2}{*}{ Роки } & \multirow{2}{*}{$\begin{array}{c}\text { Загальні обсяги прямих } \\
\text { інвестицій, млн дол. США }\end{array}$} & \multicolumn{2}{|c|}{ У тому числі } \\
\cline { 3 - 4 } & 45370,0 & 36969,1 & 25214,5 \\
\hline 2010 & 48197,6 & 39268,9 & 24480,6 \\
\hline 2011 & 51705,3 & 41132,3 & 22772,2 \\
\hline 2012 & 53704,0 & 41032,8 & 20879,1 \\
\hline 2013 & 38356,8 & 29308,0 & 15362,8 \\
\hline 2014 & 32122,5 & 24982,8 & 13347,9 \\
\hline 2015 & 31230,3 & 23425,7 & 12936,9 \\
\hline 2016 & 31606,4 & 24145,2 & 13400,8 \\
\hline 2017 & 32905,1 & 25972,3 & 14475,1 \\
\hline 2018 & 35809,6 & 28289,3 & 16029,7 \\
\hline 2019 & &
\end{tabular}

Джерело: складено за даними: [17].

неефективність системи державного управління; а до зовнішніх викликів: розчарування європейських партнерів в євроінтеграційних можливостях України, відсутність дієвих міжнародних гарантій для України.

17-21 січня 2020 р. соціологічною службою Центру Разумкова було проведено дослідження «Рівень підтримки громадянами вступу України до СС і НАТО». Було опитано 2000 респондентів у всіх регіонах України. Теоретична похибка вибірки становить 2,3\%. На питання «Якби найближчим часом відбувся референдум з приводу вступу України до СС, Ви би відповіли»: «за» - 63,3\%; «проти»-21,6\%; «не брали б участі у референдуму» - 5,9\%; «не визначилися з відповіддю»$9,1 \%$. На запитання «Якби найближчим часом відбувся референдум з приводу вступу України до НАТО» одержано такі відповіді: «за»-49,8\%; «проти» - 29,8\%; «не брали б участі у референдуму» - 7,3\%; «не визначилися з відповіддю» - 13,1\%.

У результаті проведеного статистичного аналізу й узагальнення різних наукових точок зору стосовно виявлення переваг, недоліків, загроз, перспективних напрямів європейської інтеграції виконано SWOTаналіз (таблиця 7).

Висновки. У результаті дослідження визначено політико-економічні засоби інтеграції України у Свропейську спільноту в умовах реалізації Угоди про асоціацію, серед них:

- ефективна співпраця з Свропейським інвестиційним банком, Свропейським банком реконструкції і розвитку та іншими міжнародними фінансовими організаціями для підтримки розвитку різних сфер економічної діяльності;
- гармонізація національного законодавства 3 правом ЄC;

- активна участь України у формуванні стратегічних документів подальшого розвитку ЄС у статусі рівноправного партнера з метою захисту національних і загальноєвропейських інтересів;

- забезпечення верховенства права;

- реформування судової, конституційної, виборчої систем;

- реалізація демократичних принципів прав людини;

- формування правового кодексу 3 регулювання міграційних процесів у рамках Угоди про реадмісію між Україною та ЄС;

- боротьба з корупцією;

- реалізація стратегії випереджувального розвитку, тобто забезпечення щорічних темпів зростання ВВП в Україні, істотного подолання розриву в обсягах ВВП на одну особу між Україною та державами-членами СС;

- модернізація державного управління та системи професійного навчання держслужбовців;

- трансформація засад регіонального управління та застосування смарт-спеціалізації при розробці стратегій регіонального розвитку;

- взаємодія органів влади та територіальної громади;

- вдосконалення місцевого самоврядування;

- фінансове регулювання інвестиційної діяльності;

- реалізація конкурентного комплаєнсу задля охорони відносин економічної конкуренції;

- утвердження України як високотехнологічної держави на основі реалізації інноваційної моделі в контексті економіки знань і STEM-підходу; 
Таблиця 7 - Матриця SWOT-аналізу інтеграції України у Європейську спільноту

\begin{tabular}{|c|c|}
\hline Сильні сторони & Слабкі сторони \\
\hline \begin{tabular}{|l}
\multicolumn{1}{|c|}{ Політичні: } \\
розбудова демократичних інституцій; \\
адаптація національного законодавства із законодавством СС; \\
європейська колективна безпека
\end{tabular} & $\begin{array}{l}\text { Політичні: } \\
\text { часткова втрата суверенітету держави; } \\
\text { недостатня визначеність України у стратегічних програмах } \\
\text { розвитку ЄС; } \\
\text { погіршення взаємовідносин з РФ через анексію Криму й } \\
\text { бойові події на Сході; } \\
\text { вихід Великої Британії із СС (Brexit) }\end{array}$ \\
\hline $\begin{array}{l}\text { Економічні: } \\
\text { макроекономічна стабільність; } \\
\text { залучення додаткових фінансових ресурсів; } \\
\text { надання субсидій сільському господарству; } \\
\text { зростання позитивного сальдо зовнішньоторговельного } \\
\text { балансу; } \\
\text { спільні митні тарифи; } \\
\text { антидемпінгова політика; } \\
\text { протекціонізм і контроль за експортом; } \\
\text { вихід на нові ринки збуту для української продукції; } \\
\text { інноваційна та технологічна модернізація; } \\
\text { широкий доступ до інформаційного середовища СС; } \\
\text { забезпечення вільного доступу до інноваційних та } \\
\text { інформаційних технологій; приєднання України до єдиної } \\
\text { транспортної мережі }\end{array}$ & 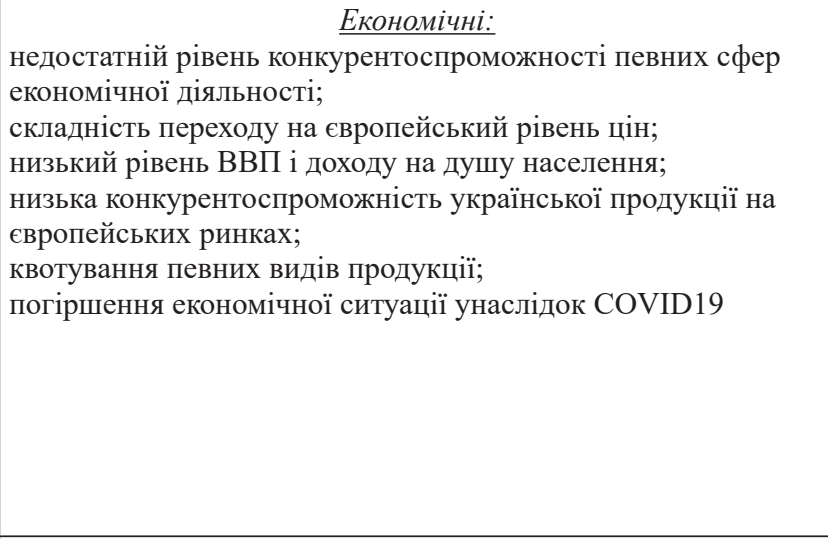 \\
\hline \begin{tabular}{l}
\multicolumn{1}{c}{ Сочіальні: } \\
ефективний захист прав людини \\
в інституціях ЄС; розширення можливостей для освіти, \\
роботи й відпочинку і туризму; відкриття кордонів для \\
вільного пересування населення; \\
впровадження соціальних стандартів у сферах охорони \\
здоров’я та освіти; \\
забезпечення високого рівня життя населення, яке б \\
відповідало європейському рівню; формування розвиненої \\
системи захисту довкілля відповідно до європейських норм \\
і стандартів
\end{tabular} & $\begin{array}{l}\frac{\text { Cочіальні: }}{\text { зниження рівня платоспроможності населення через }} \\
\text { ускладнення епідеміологічної ситуації у світі; } \\
\text { зростання міграційних потоків }\end{array}$ \\
\hline Можливості & Загрози \\
\hline $\begin{array}{l}\text { Політичні: } \\
\text { формування правової держави та громадянського } \\
\text { суспільства; } \\
\text { встановлення стабільної політичної системи; } \\
\text { сприяння України як важливого суб’єкта політичних } \\
\text { відносин; } \\
\text { зменшення корупції; } \\
\text { реформування судочинства; } \\
\text { членство в НАТО; }\end{array}$ & $\begin{array}{c}\text { Політичні: } \\
\text { небезпека втягнення України в конфліктні ситуації } \\
\text { (наприклад, між Заходом і мусульманським світом) }\end{array}$ \\
\hline 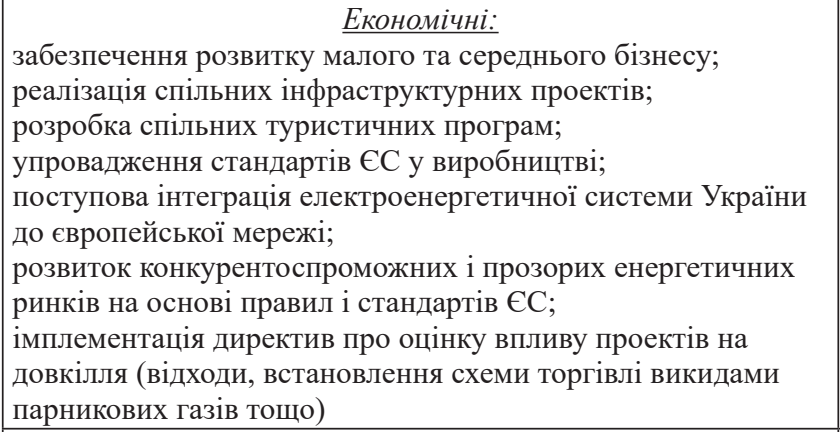 & 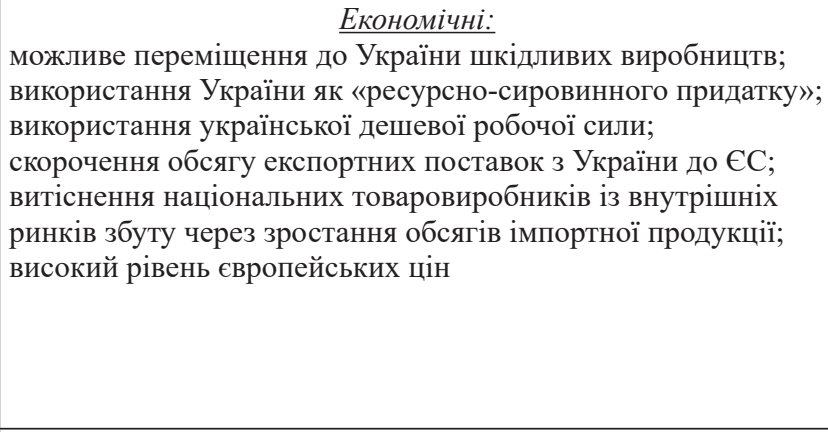 \\
\hline $\begin{array}{l}\text { Соціальні: } \\
\text { реалізація спільних програм з реформування освіти, науки, } \\
\text { охорони здоров’я, соціального захисту; } \\
\text { розширення прав і можливостей на вільне } \\
\text { працевлаштування; } \\
\text { активізація соціального партнерства між урядом, бізнесом і } \\
\text { працівниками }\end{array}$ & $\begin{array}{l}\text { Cочіальні: } \\
\text { поглиблення демографічного спаду; } \\
\text { незаконна міграція; } \\
\text { відтік висококваліфікованих кадрів; } \\
\text { зростання рівня безробіття }\end{array}$ \\
\hline
\end{tabular}

Джерело: узагальнено й складено за даними: [6, с. 74; 10, с. 756; 11, с. 64-66; 12, c. 116] 
- інтеграція до європейських ринків: промислових товарів, фінансових послуг, поштових послуг, газу;

- взаємне відкриття ринків державних закупівель;

- інтеграція до єдиної транспортної мережі й Європейського спільного авіаційного простору;

- спрощення митних процедур;

- тарифні квоти на експорт СС;

- впровадження механізму валютної лібералізації;

- забезпечення вільного руху капіталу, пов'язаного 3 надходженням прямих і портфельних інвестицій, наданням кредитів, фінансових позик;
- модернізація наявної енергетичної інфраструктури, безпека енергетичних мереж;

- удосконалення соціальних стандартів оплати праці;

- імплементація нормативно-правових актів ЄС до правової системи України з екологічних питань;

- формування механізмів циркулярної економіки в контексті концепції «зеленого» зростання.

У подальших дослідженнях планується розробити пропозиції щодо вдосконалення нормативно-правового регулювання євроінтеграційних процесів у різних сферах економічної діяльності в Україні.

\section{Список використаних джерел:}

1. Spiliopoulos O. The EU-Ukraine Association Agreement As A Framework Of Integration Between The Two Parties. The Economies of Balkan and Easters Europe Countries in Changed World (EBEEC 2013). Procedia Economics and Finance. 2014. Vol. 9. P. 256-263. https://doi.org/10.1016/S2212-5671(14)00027-6.

2. Davydchyk M., Mehlhausen T., Priesmeyer-Tkocz W. The price of success, the benefit of setbacks: Alternative futures of EU-Ukraine relations. Futures. 2018. Vol. 97. P. 35-46. https://doi.org/10.1016/ j.futures.2017.06.004

3. Yakymenko Yu., Pashkov M. Ukraine on the path to the EU: citizens' opinions and hopes. TEPSA Briefs. 2018. October. URL: http://www.tepsa.eu/wp-content/uploads/2018/10/Ukrainian_brief_final-version.pdf (дата звернення: 13.06.2020).

4. Копійка В. В., Шинкаренко Т. І. Європейський Союз: заснування і етапи становлення. Київ: Видавничий Дім «Ін Юре», 2001. $448 \mathrm{c}$

5. Рябінін Є. Проблеми інтеграції у XX столітті: основні концепції їх вивчення. Політичний менеджмент. 2006. № 5. C. 122-130.

6. Осадча Н. В. Характеристика процесу інтеграції України до Європейського Союзу (ЄС). Економічний вісник Донбасу. 2011. № 3(25). С. 71-81.

7. Європейський проект та Україна: аналіт. доповідь / Б. О. Парахонський, Г. М. Яворська, О. А. Резнікова, О. В. Снігир; за заг. ред. О. В. Литвиненка. Київ: НІСД, 2012. 64 с.

8. Даниленко Л. І., Полішук І. В. Перспективи та виклики євроінтеграційних процесів для України: навч. - метод. матеріали. Київ: НАДУ, 2013. 132 с.

9. Машталір Х., Леськів С. Інтеграція України до Європейського Союзу як основа для розбудови громадянського суспільства. Підприємництво, господарство і право. 2017. № 6. С. 163-166.

10. Тодощук А. В., Батюк I. І., Шеремета А. І. Україна в інтеграційних процесах: ризики та переваги. Молодий вчений. 2017. № 5(45). С. 753-757.

11. Степаненко Н. О., Степаненко В. О. Інтеграція України до Європейського Союзу: переваги та недоліки. Вісник економіки транспорту і промисловості. 2018. № 61. С. 62-67.

12. Кваша О. С., Синякова А. В. Україна та ЄС: проблеми та перспективи інтеграції в сучасних умовах. Науковий вісник Ужгородського національного університету. Серія: Міжнародні економічні відносини та світове господарство. 2019. Вип. 23. Ч. 1. С. 112-117.

13. Україна в європейському науково-освітньому та інноваційному просторі: концепція адаптації та інтеграції в умовах Угоди про асоціацію з Європейським Союзом: навч.-наук. видання / С. В. Іванов, В. І. Ляшенко, І. Ю. Підоричева та ін.; НАН України, Ін-т економіки пром-сті. Київ, 2019. 312 с.

14. Співробітництво між Україною та країнами СС у 2014 році: стат. збірник. Київ: Державна служба статистики України, 2015. $270 \mathrm{c}$

15. Співробітництво між Україною та країнами ЄС у 2015 році: стат. збірник. Київ: Державна служба статистики України, 2016. $195 \mathrm{c}$.

16. Співробітництво між Україною та країнами СС у 2018 році: стат. збірник. Київ: Державна служба статистики України, 2019. $74 \mathrm{c}$.

17. Прямі інвестиції з країн ЄС в економіці України за 2010-2019 роки. Офіційний сайт Державної служби статистики України. URL: http://www.ukrstat.gov.ua/ (дата звернення: 13.06.2020).

\section{References:}

1. Spiliopoulos O. (2014) The EU-Ukraine Association Agreement As A Framework Of Integration Between The Two Parties. The Economies of Balkan and Easters Europe Countries in Changed World (EBEEC 2013). Procedia Economics and Finance, vol. 9 , pp. 256-263. https://doi.org/10.1016/S2212-5671(14)00027-6

2. Davydchyk M., Mehlhausen T., Priesmeyer-Tkocz W. (2018) The price of success, the benefit of setbacks: Alternative futures of EU-Ukraine relations. Futures, vol. 97, pp. 35-46. https://doi.org/10.1016/ j.futures.2017.06.004

3. Yakymenko Yu., Pashkov M. (2018) Ukraine on the path to the EU: citizens' opinions and hopes. TEPSA Briefs. October. Available at: http://www.tepsa.eu/wp-content/uploads/2018/10/Ukrainian_brief_final-version.pdf (accessed 13 June 2020).

4. Kopiika V. V., Shynkarenko T. I. (2001) Yevropeiskyi Soiuz: zasnuvannia i etapy stanovlennia [European Union: the foundation and stages of formation]. Kyiv: Vydavnychyi Dim «In Yure».

5. Riabinin Ye. (2006) Problemy intehratsii u XX stolitti: osnovni kontseptsii yikh vyvchennia [Problems of integration in the XX century: the basic concepts of their study]. Political management, no. 5, pp. 122-130.

6. Osadcha N. V. (2011) Kharakterystyka protsesu intehratsii Ukrainy do Yevropeiskoho Soiuzu (YeS) [Characteristics of the process of Ukraine's integration into the European Union (EU)]. Economic Herald of the Donbas, no. 3(25), pp. 71-81.

7. Parakhonskyi B. O., Yavorska H. M., Reznikova O. A., Snihyr O. V. (2012) Yevropeiskyi proekt ta Ukraina [European project and Ukraine]. Kyiv: NISR. 
8. Danylenko L. I., Polishchuk I. V. (2013) Perspektyvy ta vyklyky yevrointehratsiinykh protsesiv dlia Ukrainy [Perspectives and challenges of European integration processes for Ukraine]. Kyiv: NAPA.

9. Mashtalir Kh., Leskiv S. (2017) Intehratsiia Ukrainy do Yevropeiskoho Soiuzu yak osnova dlia rozbudovy hromadianskoho suspilstva [Integration of Ukraine into the European Union as a basis for building civil society]. Entrepreneurship, economy and law, no. 6 , pp. 163-166.

10. Todoshchuk A. V., Batiuk I. I., Sheremeta A. I. (2017) Ukraina v intehratsiinykh protsesakh: ryzyky ta perevahy [Ukraine in integration processes: risks and benefits]. Young scientist, no. 5(45), pp. 753-757.

11. Stepanenko N. O., Stepanenko V. O. (2018) Intehratsiia Ukrainy do Yevropeiskoho Soiuzu: perevahy ta nedoliky [Ukraine's integration into the European Union: advantages and disadvantages]. Bulletin of Transport Economics and Industry, no. 61, pp. 62-67.

12. Kvasha O. S., Syniakova A. V. (2019) Ukraina ta YeS: problemy ta perspektyvy intehratsii v suchasnykh umovakh [Ukraine and the EU: problems and prospects of integration in modern conditions]. Scientific Bulletin of Uzhhorod National University. Series: International economic relations and the world economy, vol. 23, issue 1, pp. 112-117.

13. Ivanov S. V., Liashenko V. I., Pidorycheva I. Yu. et al. (2019) Ukraina v yevropeiskomu naukovo-osvitnomu ta innovatsiinomu prostori: kontseptsiia adaptatsii ta intehratsii v umovakh Uhody pro asotsiatsiiu z Yevropeiskym Soiuzom [Ukraine in the European scientific-educational and innovative space: the concept of adaptation and integration in the Association Agreement with the European Union]. Kyiv: IIE of NAS of Ukraine.

14. State Statistics Service of Ukraine (2015) Spivrobitnytstvo mizh Ukrainoiu ta krainamy YeS u 2014 rotsi [Cooperation between Ukraine and EU countries in 2014]. Kyiv.

15. State Statistics Service of Ukraine (2016) Spivrobitnytstvo mizh Ukrainoiu ta krainamy YeS u 2015 rotsi [Cooperation between Ukraine and EU countries in 2015]. Kyiv.

16. State Statistics Service of Ukraine (2019) Spivrobitnytstvo mizh Ukrainoiu ta krainamy YeS u 2018 rotsi [Cooperation between Ukraine and EU countries in 2018]. Kyiv.

17. State Statistics Service of Ukraine (2020) Priami investytsii z krain YeS v ekonomitsi Ukrainy za 2010-2019 roky [Direct investments from EU countries in the economy of Ukraine for 2010-2019]. Available at: http://www.ukrstat.gov.ua/ (accessed 13 June 2020).

Ilchenko Tetiana

Dnipro State Agrarian and Economic University

\section{POLITICAL AND ECONOMIC MEANS OF UKRAINE'S INTEGRATION TO THE EUROPEAN COMMUNITY}

Strengthening relations between the European Union and Ukraine is a political and economic priority. To achieve this, it is necessary to implement a regime of partnership and cooperation in various fields. In this regard, the purpose of this study is to identify the advantages, disadvantages, threats, risks, opportunities and promising areas of European integration through SWOT-analysis and determine the political and economic means of its implementation in Ukraine. The article uses general scientific methods of abstraction and analogy, induction and deduction, analysis and synthesis, generalization, structural-logical, SWOT-analysis, statistical, sociological surveys. The history of partnership relations between Ukraine and the EU is studied. The key areas of economic integration of Ukraine and the EU are established, where cooperation with international financial organizations financing programs in various fields of economic activity is a priority of relations. The statistical analysis of indicators of the consolidated foreign trade balance of Ukraine with the EU countries is carried out: volumes of export of the goods and services, volumes of import of the goods and services, balance of export-import operations, parity between export and import. The results of the conducted sociological polls in order to identify the level of support of citizens for Ukraine's accession to the European Union are presented. A matrix of SWOT-analysis of Ukraine's integration into the European Community is proposed, which contains advantages, disadvantages, threats and perspective directions. As a result of the study, the political and economic means of Ukraine's integration into the European Community were identified in the context of the Association Agreement, where the main ones are: effective cooperation with the international financial organizations to support the development of various areas of economic activity; implementation of democratic principles of human rights; fight against corruption; transformation of the principles of regional management and the use of smart specialization in the development of regional development strategies.

Key words: European integration, single European space, political and economic means, partnership regime, SWOTanalysis, priority areas of cooperation.

JEL classification: F02, F15, O52 